\title{
Mendeteksi Pemahaman Konsep Perkalian Mahasiswa Calon Guru Madrasah Ibtidaiyah Melalui Problem Posing
}

\author{
Marhayati ${ }^{1}$, Nuril Huda ${ }^{2}$ \\ 1,2Universitas Islam Negeri Maulana Malik Ibrahim Malang, Indonesia \\ 1marhayati@uin-malang.ac.id, 2nurilhuda26@uin-malang.ac.id
}

DOI: $10.18860 /$ mad.v12i1.7864

Abstract. This study aims to determine the understanding of the mathematical multiplication concept of Islamic Elementary School prospective teachers. This study applied a descriptive qualitative method. The research subjects were 33 students of Islamic Elementary Teacher Education Department at the Islamic State University of Maulana Malik Ibrahim Malang. Mathematics problem posing is the learning strategy used in the Pembelajaran Matematika course. The results of data analysis show that there are three categories understand the concept of multiplication: (1) understand the concept of intact multiplication is $33.3 \%$, which means students are able to mention the definition, know the meaning of multiplication and show the multiplication structure by grouping objects, (2) understand the concept of pseudo multiplication is $18.2 \%$ in which students can mention the definition, know the meaning of multiplication but they are not able to show the multiplication structure by grouping objects, (3) not understand the concept of multiplication is $48.5 \%$ which means that students can mention the definition but do not know the meaning of multiplication and fail to show the multiplication structure by grouping objects.

Keywords. Consep; multiplication; mathematics; problem posing

\begin{abstract}
Abstrak. Penelitian ini bertujuan untuk mengetahui pemahaman konsep perkalian matematika calon guru madrasah ibtidaiyah. Penelitian yang dilakukan merupakan deskriptif kualitatif. Subjek penelitian yang dilaporkan merupakan mahasiswa calon guru madrasah ibtidaiyah di Universitas Islam Maulana Malik Ibrahim Malang. Ada 33 mahasiswa yang diambil sebagai subjek penelitian. Pengajuan soal matematika merupakan pembelajaran yang diterapkan didalam penelitian ini yakni pada matakuliah Pembelajaran Matematika. Hasil analisis data menunjukkan terdapat tiga kategori pemahaman konsep perkalian yaitu (1) paham konsep perkalian utuh sebanyak 33,3\% artinya mampu menyebutkan definisi, mengetahui makna perkalian dan menunjukkan struktur perkalian dengan pengelompokkan objek, (2) paham konsep perkalian semu sebanyak $18,2 \%$ artinya mampu menyebutkan definisi, mengetahui makna perkalian tetapi belum dapat menunjukkan struktur perkalian dengan pengelompokkan objek, (3) tidak paham konsep perkalian sebanyak 48,5\% artinya mampu menyebutkan definisi namun belum mengetahui makna perkalian dan gagal menunjukkan struktur perkalian dengan pengelompokkan objek.
\end{abstract}

Kata kunci. konsep; perkalian; matematika; pengajuan soal

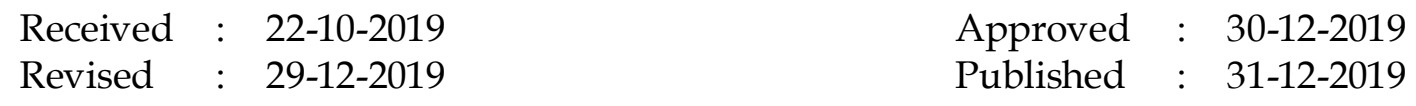

Copyright (C Madrasah Jurnal Pendidikan dan Pembelajaran Dasar. All Right Reserved.

This is an open access article under the CC BY-NC-ND license

(http://creativecommons.org/licenses/by-nc-nd/4.0/).

Correspondence Address: marhayati@uin-malang.ac.id 


\section{A. PENDAHULUAN}

Mahasiswa calon guru madrasah ibtidaiyah (MI)/ sekolah dasar (SD) wajib memahami dan menguasai konsep-konsep materi yang akan diajarkan pada siswa di MI/SD. Salah satu mata pelajaran yang sangat penting adalah matematika. Mata pelajaran matematika diberikan untuk membekali siswa MI/SD dalam menumbuhkan berfikir logis, kritis dan cermat serta tidak mudah menyerah dalam memecahkan masalah (Kemeterian Pendidikan dan Kebudayaan, 2017:1). Seyogyanya mahasiswa calon guru MI/SD wajib memahami konsep-konsep matematika dengan baik. Konsepkonsep dalam matematika saling terkait, maka calon guru MI/SD sangat berperan penting dalam menyampaikan konsep matematika dengan benar sebagai dasar pemahaman pada materi-materi selanjutnya. Dengan kata lain, seorang calon guru harus dapat memperluas pemahamannya ketika merencakan, mengajarkan, dan mengevaluasi kemajuan siswa (Chang, 2007).

Salah satu materi yang terdapat dalam silabus matematika MI/SD adalah perkalian (Kemeterian Pendidikan dan Kebudayaan, 2017:5). Konsep perkalian yang mendasar adalah penjumlahan yang berulang (Hino \& Kato, 2019; Park \& Nunes, 2001). Model perkalian adalah memahami makna, membayangkan/mengambarkan dan memikirkan perkalian (Beckmann, 2007:195). Mahasiswa tidak hanya paham definisi perkalian namun dapat menunjukkannya dalam bentuk struktur perkalian. Makna perkalian yaitu misalkan A dan B bilangan tak negatif maka $A \times B$ dibaca "A kali B" bermakna total objek dalam A kelompok jika terdapat B objek disetiap kelompok (Beckmann, 2007:196). Misalkan terdapat tiga kantong dan masing kantong terisi empat kelereng maka total kelereng adalah $3 \times 4=4+4+4=12$, sehingga total ada 12 kelereng (Project, 2007).

Cara lain untuk menunjukkan situasi perkalian adalah menggunakan struktur perkalian dengan pengelompokan objek. Perkalian dinyatakan sebagai sekelompok objek dalam beberapa grup A dengan B objek dalam masing-masing grup dapat ditulis $A \times B$ (Beckmann, 2007:196). Misalkan terdapat tiga kantong dan masing kantong terisi empat kelereng dapat dinyatakan dalam bentuk struktur perkalian dengan pengelompokkan, disajikan dalam Gambar A.1.

Gambar A.1. Struktur perkalian dengan pengelompokan objek

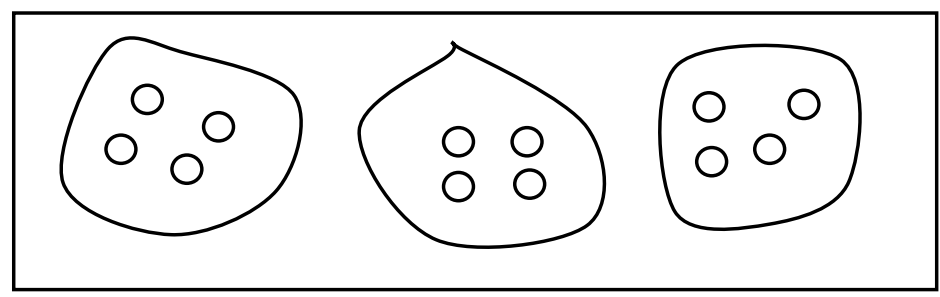

Mahasiswa calon guru dikatakan memahami konsep perkalian jika dapat menunjukkannya secara definisi maupun struktur perkalian dengan pengelompokan objek. Mahasiswa calon guru MI/SD harus memahai konsep perkalian dengan baik agar tidak terjadi kesalahan pada saat mengajar. Ketika mahasiswa calon guru diberikan pertanyaan tentang definisi perkalian, tentu saja dapat dengan mudah dijawab yaitu perkalian merupakan penjumlahan yang berulang. Ketika mahasiswa diberikan soal $4 \times 5$, tentu dengan mudah dapat dijawab hasilnya 20. Bisa jadi tanpa melakukan perhitungan terlebih dahulu karena sudah ada dalam memori sehingga bisa memanggil 


\section{MADRASAH}

Jurnal Pendidikan dan Pembelajaran Dasar

p ISSN: 1979-5599 | e ISSN: 2502-194X

Page | 65

dari ingatan (Krulik, S., Rudnick, J.A, \& Milou, 2003:39). Namun sebagai calon guru MI/SD, mahasiswa harus mampu menjelaskan konsep perkalian dengan baik dan benar.

Untuk mengetahui sejauh mana pemahaman konsep perkalian mahasiswa calon guru MI/SD, salah satu cara yang dapat digunakan yaitu melalui pengajuan masalah/soal (problem posing). Problem posing merupakan komponen yang menyatu dalam matematika sekolah (Singer, Ellerton, \& Cai, 2013). Problem posing bisa digunakan sebagai alat pembelajaran maupun untuk diagnosa (Tichá \& Hošpesová, 2013). Pada penelitian ini pengajuan soal matematika digunakan untuk mendiagnosa pemahaman konsep perkalian mahasiswa. Mahasiswa diajak untuk membuat soal tentang perkalian. Melalui soal yang hasilkan, dapat ditelusuri pemahaman mahasiswa tentang konsep perkalian.

Praktek pengajuan soal penting bagi mahasiswa calon guru, karena dapat menumbuhkan pengetahuan dan pengalaman dalam membuat soal matematika (Erdik, 2019; Lee, Bicer, Kwon, \& Capraro, 2019; Toluk-Uçar, 2009), serta mendukung penalaran matematis (Kurniawan, 2010). Eksplorasi situasi matematika dapat meningkatkan kualitas soal yang diajukan dan meningkatkan pemahaman matematis mahasiswa (Crespo \& Sinclair, 2008). Diharapkan mahasiswa calon guru terbiasa untuk membuat soal yang tidak hanya fokus pada pemahaman hafalan dan prosedural namun sekaligus soal yang menggali penalaran dan pemahaman konseptual. Selama ini di dalam kelas, guru fokus pada pemahaman hafalan dan prosedural dari pada penalaran matematika dan pemahaman konseptual (Crespo \& Sinclair, 2008).

Hasil penelitian Silver.E.A, Mamona-Downs, \& Leung. S.S (1996) menunjukkan bahwa ketika diminta untuk membuat perluasan dari masalah matematika yang diberikan, baik guru maupun calon guru menghasilkan masalah yang dapat diprediksi, ringan, tidak dirumuskan dengan baik, dan tidak dapat diselesaikan. Lebih lanjut hasil penelitian Mallart, Font, \& Diez (2018) diketahui bahwa kesulitan calon guru dalam pengajuan masalah diantaranya yaitu membuat masalah yang dikenali siswa relevan dalam kehidupan sehari, dan masalah yang sesuai dengan kurikulum sekolah pada tingkat pendidikan tertentu. Mahasiswa calon guru seharusnya sudah terbiasa dengan kegiatan pengajuan soal matematika agar memiliki keterampilan membuat soal dan meningkatkan kemampuan matematisnya. Pengajuan soal matematika juga dapat digunakan sebagai alat untuk mendeteksi kemampuan matematis mahasiswa. Dalam perumusan soal, semua kemampuan matematis mahasiswa digunakan untuk membuat soal. Oleh karena itu, kualitas soal yang diajukan mahasiswa dapat menunjukkan sejauh mana kemampuan matematisnya. Penelitian ini bertujuan untuk mengetahui pemahaman konsep perkalian mahasiswa calon guru melalui pengajuan masalah/soal matematika.

\section{B. METODE PENELITIAN}

Penelitian ini merupakan deskriptif kualitatif. Subjek penelitian yang dilaporkan adalah mahasiswa calon guru madrasah ibtidaiyah UIN Maulana Malik Ibrahim Malang sebanyak 33 mahasiswa. Pembelajaran yang diterapkan dalam penelitian ini adalah pengajuan soal matematika pada matakuliah Pembelajaran Matematika. Mahasiswa diminta untuk mengajukan soal tanpa disertai penyelesainnya.

Informasi yang diberikan kepada mahasiswa berupa situasi semi terstruktur (Stoyanova \& Ellerton, 1996). Kegiatan pengajuan soal dilakukan setelah mahasiswa 
menyelesaikan masalah (Silver \& Cai, 1996). Mahasiswa diberi situasi/informasi berupa silabus matematika kelas II Madrasah Ibtidaiyah (Kemeterian Pendidikan dan Kebudayaan, 2017), khususnya mengenai materi perkalian. Berdasarkan Informasi tersebut, mahasiswa diminta untuk menjawab pertanyaan dan membuat soal. Gambar A.2 menunjukkan informasi yang diberikan kepada mahasiswa.

Gambar A.2 Situasi/informasi yang diberikan kepada mahasiswa

Silabus Matematika Kelas II MI/SD.

\begin{tabular}{|c|c|c|}
\hline Kompetensi Dasar: & $\begin{array}{l}\text { Materi } \\
\text { Pokok: }\end{array}$ & Pembelajaran: \\
\hline $\begin{array}{l}\text { Siswa mampu: } \\
\text { 3.4 Menjelaskan perkalian } \\
\text { dan pembagian yang } \\
\text { melibatkan bilangan } \\
\text { cacah dengan hasil } \\
\text { kali sampai dengan } \\
100 \text { dalam kehidupan } \\
\text { sehari-hari serta } \\
\text { mengaitkan perkalian } \\
\text { dan pembagian }\end{array}$ & $\begin{array}{l}\text { Perkalia } \\
\text { n dan } \\
\text { pembag } \\
\text { ian } \\
\text { bilanga } \\
\text { n cacah }\end{array}$ & $\begin{array}{l}\text { - Mengamati operasi penjumlahan berulang } \\
\text { - Menyimpulkan bahwa perkalian sebagai } \\
\text { penjumlahan berulang } \\
\text { - Membuat contoh penjumlahan berulang dan } \\
\text { menggantikannya menjadi operasi perkalian } \\
\text { - Menyelesaikan soal cerita yang menggunakan } \\
\text { tokoh dan isi cerita yang berhubungan dengan } \\
\text { perkalian } \\
\text { - Mengerjakan soal yang berhubungan dengan } \\
\text { masalah sehari-hari yang melibatkan perkalian } \\
\text { dan pembagian }\end{array}$ \\
\hline
\end{tabular}

Berdasarkan informasi yang diberikan mahasiswa diperintahkan untuk menjawab pertanyan dan membuat soal. Berikut ini perintah yang diberikan kepada mahasiswa:

1. Jelaskan bagaimana Anda mengajaran materi perkalian pada siswa kelas $2 \mathrm{MI} / \mathrm{SD}$ dengan mengunakan media atau alat peraga!

2. Buatlah minimal 5 soal untuk mengevaluasi pemahaman siswa tentang materi perkalian!

\section{HASIL DAN PEMBAHASAN}

Hasil penelitian diperoleh tiga kelompok pemahaman konsep perkalian mahasiswa yaitu (1) paham konsep perkalian utuh, (2) paham konsep perkalian semu, dan (3) tidak paham konsep perkalian. Ringkasan hasil pemahaman konsep perkalian mahasiswa ditunjukkan dalam Tabel 1.

Tabel 1. Pemahaman Konsep Perkalian Mahasiswa

\begin{tabular}{cccc}
\hline No & Pemahaman Konsep Perkalian & Banyak Mahasiswa & $\begin{array}{c}\text { Persentase } \\
\mathbf{( 1 0 0 \% )}\end{array}$ \\
\hline 1. & paham konsep perkalian utuh & 11 & $33,3 \%$ \\
\hline 2. & Paham konsep perkalian semu & 6 & $18,2 \%$ \\
\hline 3 & Tidak paham konsep perkalian & 16 & $48,5 \%$ \\
\hline
\end{tabular}




\section{MADRASAH}

Jurnal Pendidikan dan Pembelajaran Dasar

p ISSN: 1979-5599 | e ISSN: 2502-194X

Page | 67

Selanjutnya dipaparkan hasil kerja mahasiswa dari setiap kelompok. Kelompok Paham Konsep Perkalian Utuh dilaporkan satu mahasiswa yang selanjutnya disebut M1. Kelompok Paham Konsep Perkalian Semu dilaporkan satu mahasiswa selanjutnya disebut M2. Kelompok Tidak Paham Konsep Perkalian dilaporkan satu mahasiswa yang selanjutnya disebut M3.

\section{Paham Konsep Perkalian Utuh}

a. Penjelasan mahasiswa tentang mengajarkan materi perkalian pada siswa kelas 2 MI/SD dengan menggunakan media atau alat peraga.

M1 menjelaskan bahwa untuk mengajarkan perkalian bisa menggunakan media Papan Hitung. Gambar Papan Hitung tampak dalam Gambar A.3.

Gambar A.3. Media Papan Hitung

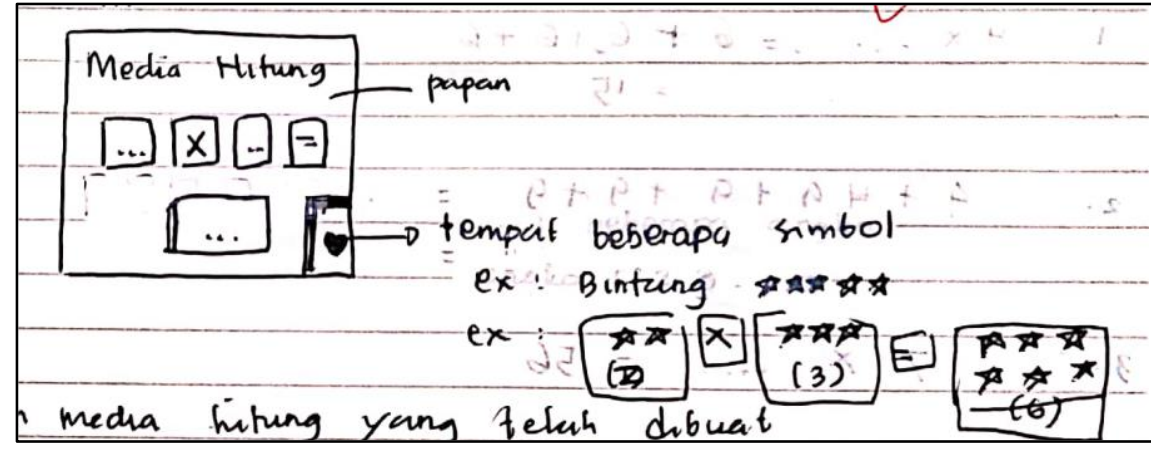

Selanjutnya diberikan contoh perkalian bilangan 4 dan 5 dalam bentuk gambar yaitu 4 bintang dan 5 bintang. Hasil kerja M1 disajikan dalam Gambar A.4.

Gambar A.4. Hasil Kerja A.4 dalam menunjukkan Stuktur Perkalian dengan Pengelompokan

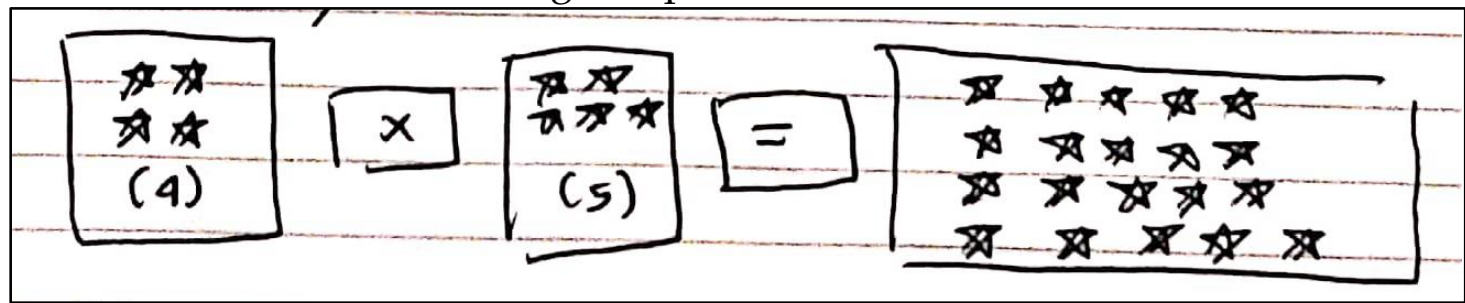

Selanjutkan merubah bentuk struktur perkalian ke simbol matematika sebagai penjumlahan berulang yaitu $4 \times 5=5+5+5+5=20$. Hasil kerja M1 disajikan dalam Gambar A.5.

Gambar A.5. Hasil kerja M1

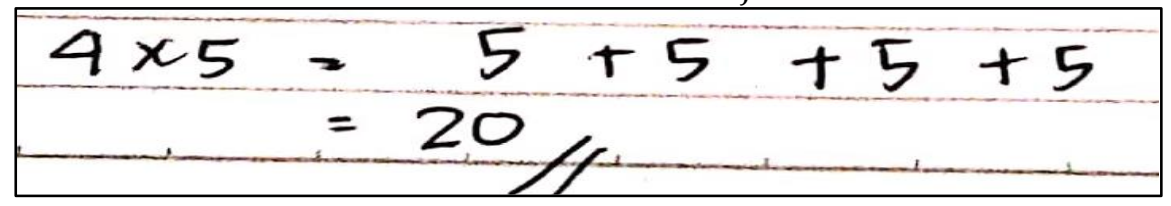

M1 menjelaskan lebih lanjut bahwa menjumlahkan 5 yang dikali 4 berarti $5+5+5+5$ (5 nya ada 4) sehingga ada 20 bintang. Hasil Kerja M1 disajkan dalam Gambar A.6. 
Gambar A.6. Hasil Kerja M1

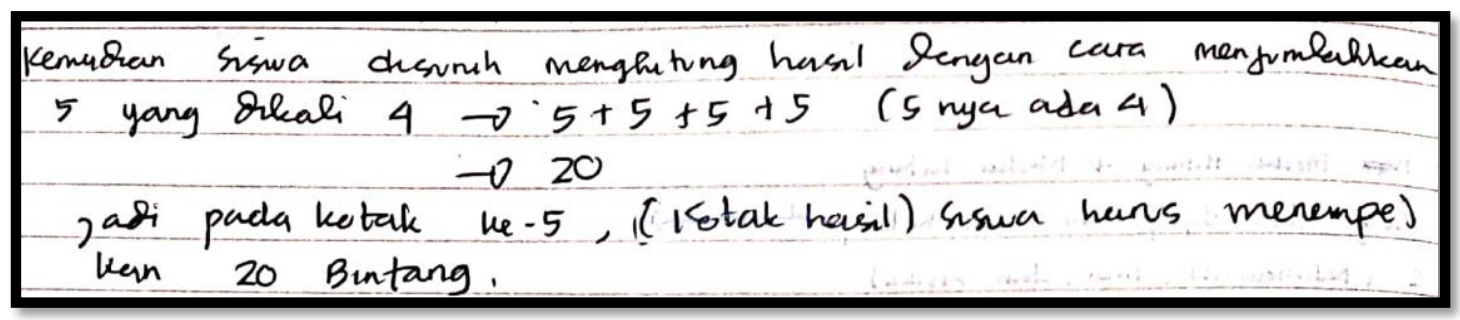

Berdasarkan Gambar A.4, A.5, dan A.6 dapat dikatakan bahwa M1 Paham makna perkalian sebagai perkalian yang berulang dan dapat menunjukkan struktur perkalian dengan pengelompokkan objek.

b. Pengajuan soal untuk mengevaluasi pemahaman siswa tentang materi perkalian Salah satu soal yang diajukan M1 yaitu tentang pengisian titik-titik dari pernyataan $9+9+9+9+9=\cdots \times 9$. M1 bisa membuat soal dengan benar yang berkaitan perkalian. Hasil kerja M1 ditunjukkan dalam Gambar A.6.

Gambar A.6. Hasil Kerja M1 dalam Pengajuan Soal Perkalian

$9+9+9+9+9=\frac{1}{9}=6$.

Berdasarkan kedua hasil kerja (a) dan (b) diketahui M1 dapat memberikan contoh dan mengajukan soal mengenai perkalian dengan benar. M1 bisa memberi contoh perkalian dalam bentuk struktur perkalian dengan pengelompokan objek kemudian menunjukkan sesuai dengan definisi perkalian (Hino \& Kato, 2019; Park \& Nunes, 2001; Vula \& Berdynaj, 2011). Hal ini dapat disimpulkan bahwa M1 memahami konsep perkalian dengan utuh dan benar. M1 dapat mengkombinasikan definisi perkalian dan grouping skills melalui trategi penjumlahan (Downton, 2008).

\section{Paham Konsep Perkalian Semu}

a. Penjelasan M2 tentang mengajarkan materi perkalian pada siswa kelas $2 \mathrm{MI} / \mathrm{SD}$ dengan menggunakan media atau alat peraga.

M2 menuliskan bahwa cara menjelaskan perkalian kepada siswa kelas 2 MI/SD dapat menggunakan "Corong Hitung". Gambar "Corong Hitung" disajikan dalam Gambar A.7.

Gambar A.7. Media Corong Hitung

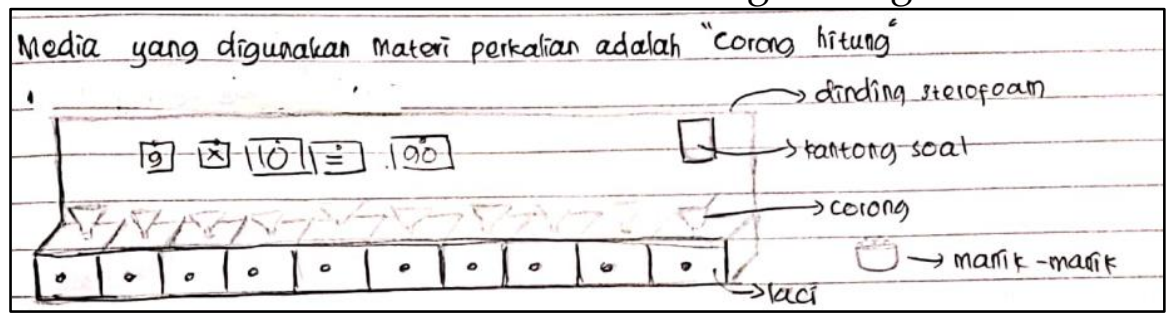




\section{MADRASAH}

Jurnal Pendidikan dan Pembelajaran Dasar

p ISSN: 1979-5599 | e ISSN: 2502-194X

Page | 69

Selanjutnya M2 dapat menyebutkan makna perkalian yaitu penjumlahan yang berulang. Selanjutnya diberikan contoh penggunaan "Corong Hitung" untuk menghitung $9 \times 10$. Dengan menggunakan "Corong Hitung", perkalian $9 \times 10$ dapat ditunjukkan dengan memasukkan sebanyak sepuluh manik-manik kedalam setiap laci sebanyak 9 laci. Sehingga dapat ditulis $9 \times 10$ merupakan $10+10+10+10+10+$ $10+10+10+10$. Hasil kerja M2 ditunjukkan dalam Gambar A.8.

Gambar A.8. Hasil Kerja M2

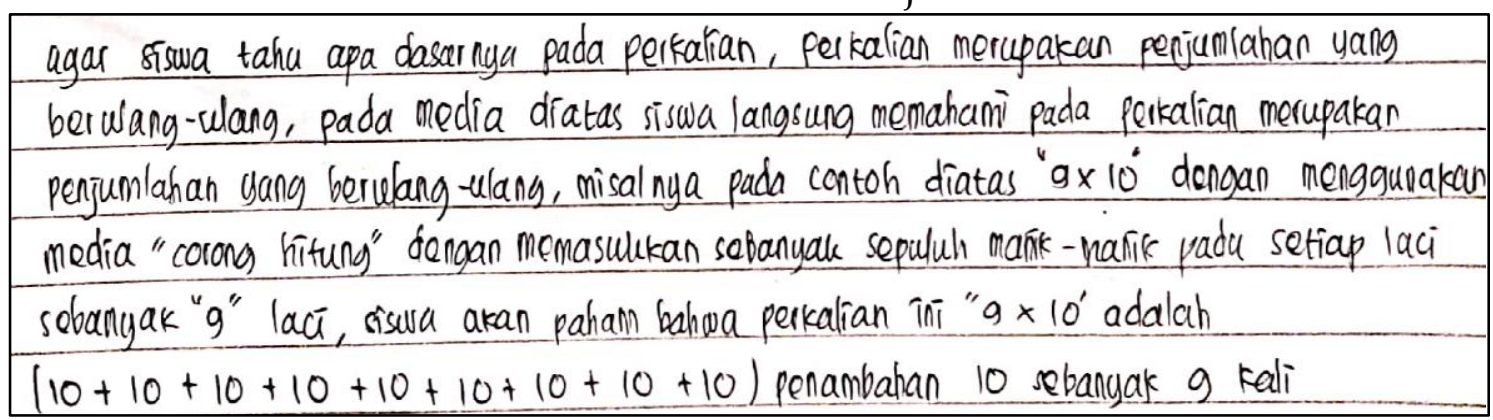

b. Pengajuan soal untuk mengevaluasi pemahaman siswa tentang materi perkalian

M2 dapat membuat lima soal untuk evaluasi pemahaman siswa tentang materi perkalian. Dari 4 soal yang diajukan, diketahui bahwa M2 dapat membuat soal perkalian yang sesuai dengan konsep perkalian. Salah satu soal yang diajukan M2 berupa pernyataan $4 \times 8=32$, dan diminta untuk menentukan jawaban yang benar jika perkalian ditulis dalam operasi jumlah. Salah satu option jawaban yang disediakan yaitu $8+8+8+8$ ini merupakan jawaban yang benar. Tampak M2 sudah paham makna perkalian. Hasil kerja M2 ditunjukkan dalam Gambar A.9.

Gambar A.9. Hasil Kerja M2 dalam Pengajuan Soal Perkalian

\begin{tabular}{l}
$4 \times 8=32$ \\
jika dituliskan pada operasi sumlah adalah... \\
a. $4 * 4+4+4$ \\
b. $8+8+4+4$ \\
c. $8+8+8+8$ \\
\hline
\end{tabular}

Ketika soal yang diajukan M2 dianalisis lebih lanjut yaitu perkalian yang disajikan dalam bentuk sturktur perkalian dengan pengelompokan ternyata ada kesalahan ketika mengubahnya kebentuk simbol matematika sebagai penjumlahan berulang. Dalam soal yang diajukan M2 disebutkan ada empat kelompok jeruk. Setiap kelompok berisi 3 jeruk. Selanjutnya diminta untuk memilih operasi perkalian yang benar. Pilihan jawaban yang disediakan M2 tidak ada yang benar, karena tidak ada yang mewakili struktur perkalian dengan pengelompokan yang diberikan. Hasil kerja M2 disajikan dalam Gambar A.10. 
Gambar A.10. Hasil Kerja M2 dalam Pengajuan Soal Perkalian

\begin{tabular}{|c|c|c|}
\hline b $b^{2}$ & 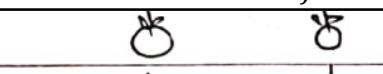 & \\
\hline$+\not{t}$ & $+d$ & $=$ \\
\hline$\ddot{b}$ & $\theta$ & \\
\hline Gambar buah & serule diatas sika & ditulis dalam oporasi perkalian odalan \\
\hline a. $3 \times 5$ & $=15$ & \\
\hline b. $3 \times 4$ & $=12$ & \\
\hline c. $3 \times 2$ & $=6$ & \\
\hline
\end{tabular}

Berdasarkan (a) dan (b) dapat diketahui bahwa M2 sudah mengetahui konsep perkalian yaitu penjumlahan yang berulang (Hino \& Kato, 2019; Park \& Nunes, 2001). Namun ketika perkalian disajikan dalam bentuk struktur perkalian dengan pengelompokan objek, M2 belum dapat menunjukkan dengan benar. M2 belum memahami konsep perkalian secara menyeluruh yaitu sesuai makna dan struktur perkalian dengan pengelompokkan objek. Hal ini menunjukkan bahwa M2 memahami konsep perkalian secara semu artinya tidak benar-benar memahami konsep perkalian secara menyeluruh.

\section{Tidak Paham Konsep Perkalian}

a) Penjelasan M3 tentang mengajarkan materi perkalian pada siswa kelas 2 MI/SD dengan menggunakan media atau alat peraga.

M3 menjelaskan bahwa media yang dapat digunakan untuk mengajarkan perkalian adalah Dakon. Contoh yang diberikan M3 yaitu perkalian $2 \times 3.3$ lubang dakon diisi 2 kerikil sehingga ada 6. Hasil kerja M3 disajikan dalam Gambar A.11.

Gambar A.11. Media Dakon

\begin{tabular}{|c|c|}
\hline Misal guru menggunakan & media dokon \\
\hline 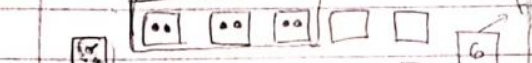 & Misal gurs memberikai soal \\
\hline$\square \square$ & Maka siswa bisa mergisi dakon tersebut \\
\hline & dengan kerikil sebanyak 2, kemudian siswo \\
\hline Dissi kerikil & merghitung ban-cak kerikil rang telah diisikan \\
\hline & ke dalam dakon (sebantak 6) \\
\hline
\end{tabular}

Berdasarkan Gambar A.11 diketahui bahwa M3 menunjukkan struktur perkalian dengan pengelompokkan. Tampak ada 3 kelompok kerikil dan setiap kelompok berisi 2 kerikil. Lebih lanjut M3 menjelaskan bahwa perkalian merupakan penjumlahan yang berulang sehingga $2 \times 3=2+2+2=6$. M3 menyimpulkan perkalian $2 \times 3$ merupakan 2 ditambahkan dengan 2 sebanyak 3 kali. Terlihat bahwa M3 belum dapat menunjukkan struktur dan makna perkalian dengan benar. Hasil kerja M3 disajikan dalam Gambar A.12. 


\section{MADRASAH}

Jurnal Pendidikan dan Pembelajaran Dasar

p ISSN: 1979-5599 | e ISSN: 2502-194X

Gambar A.12 Hasil Kerja M3

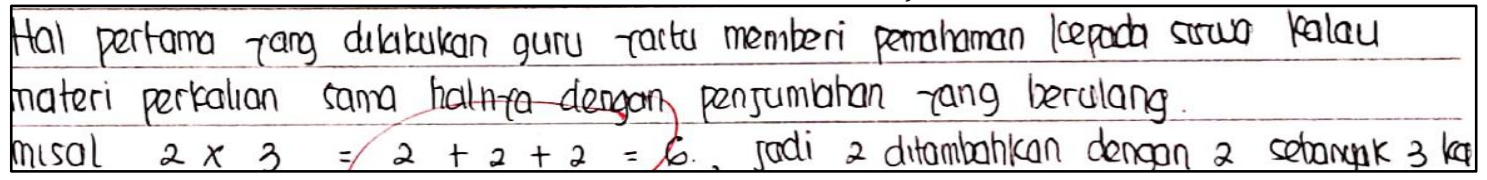

b) Pengajuan soal untuk mengevaluasi pemahaman siswa tentang materi perkalian M3 dapat membuat 5 soal. Salah satu soal yang diajukan M3 berkaitan dengan makna perkalian yaitu $4+4+4=12=4 \times \cdots$. Ini merupakan soal yang salah, seharusnya $4+4+4=12=\cdots \times 4$. Hasil kerja M3 disajikan dalam GambarA.13.

Gambar A.13. Hasil Kerja M3

$4+4+4=12=4 \times \ldots=12$. Isilah fitik disamping dengan jowaban
fang benar.

Berdasarkan (a) dan (b), M3 bisa menyebutkan definisi perkalian yaitu penjumlahan yang berulang namun gagal dalam menunjuknya (Hino \& Kato, 2019). M3 belum sesungguhnya memahami makna dan struktur perkalian dengan pengelompokkan objek (Beckmann, 2007:196 ; Downton, 2008). Dapat simpulkan bahwa M3 belum memahami konsep perkalian dan cenderung menghafal.

Mahasiswa termasuk sebagai orang dewasa. Orang dewasa ketika diberikan soal $2 \times 3$ bisa jadi tidak benar-benar menghitung untuk menentukan hasil perkalian yaitu 6 . Karena sudah ada dalam ingatan orang dewasa tentang perkalian $2 \times 3$ maka secara spontan menjawab 6. Ini menunjukkan orang dewasa menggunakan berpikir recall tidak benar-benar memikirkan sadar (Krulik, S., Rudnick, J.A, \& Milou, 2003:89). Mahasiswa calon guru tidak boleh hanya bisa mencari hasil akhir dari perkalian namun harus dapat menjelaskan definisi perkalian dan grouping skills melalui trategi penjumlahan (Downton, 2008; Hino \& Kato, 2019; Park \& Nunes, 2001).

\section{KESIMPULAN}

Pengajuan soal matematika bisa digunakan untuk mendeteksi sejauh mana pemahaman konsep perkalian mahasiswa calon guru MI/SD. Pemahaman konsep perkalian mahasiswa calon guru MI/SD dikelompokkan menjadi tiga yaitu paham konsep perkalian utuh, paham konsep perkalian semu, dan tidak paham konsep perkalian. Paham konsep perkalian utuh artinya mampu menyebutkan definisi, mengetahui makna perkalian dan menunjukkan struktur perkalian dengan pengelompokkan objek. Paham konsep perkalian semu artinya mampu menyebutkan definisi, mengetahui makna perkalian tetapi belum dapat menunjukkan struktur perkalian dengan pengelompokkan objek. Tidak paham konsep perkalian artinya mampu menyebutkan definisi namun belum mengetahui makna perkalian dan gagal menunjukkan struktur perkalian dengan pengelompokkan objek. Mahasiswa yang paham konsep perkalian utuh sebanyak 33,3\%, paham konsep perkalian semu sebanyak $18,2 \%$, dan yang tidak paham konsep perkalian $48,5 \%$. 


\section{REFERENSI}

Beckmann, S. (2007). Mathematics For Elementary Teachers (Second). United States of America: Pearson Education Inc.

Chang, N. (2007). Responsibilities of a teacher in a harmonic cycle of problem solving and problem posing. Early Childhood Education Journal, 34(4), 265-271. https:// doi.org/10.1007/s10643-006-0117-8

Crespo, S., \& Sinclair, N. (2008). What makes a problem mathematically interesting? Inviting prospective teachers to pose better problems. Journal of Mathematics Teacher Education, 11(5), 395-415. https:// doi.org/10.1007/s10857-008-9081-0

Downton, A. (2008). Links Between Children's Understanding of Multiplication and Solution Strategies For Division. In M. Goos, R. Brown, \& K. Makar (Eds.), Navigating currents and charting directions: Proceedings of the 31st annual conference of the Mathematics Education Research Group of Australasia (pp. 171-178). Retrieved from http:/ / www.merga.net.au/ documents/RP172008.pdf

Erdik, C. (2019). Investigation of mathematics teachers' opinions about problem posing. Journal on Mathematics Education, 10(1), 1-19. https://doi.org/10.22342/jme.10.1.5464.1-20

Hino, K., \& Kato, H. (2019). Teaching whole-number multiplication to promote children's proportional reasoning: a practice-based perspective from Japan. ZDM - Mathematics Education, 51(1), 125-137. https:/ / doi.org/10.1007/s11858-018-0993-6

Kemeterian Pendidikan dan Kebudayaan. (2017). Model Silabus Mata Pelajaran Sekolah Dasar Madrasah Ibtidaiyah (SD/MI). Jakarta: Kemendikbud.

Krulik, S., Rudnick, J.A, \& Milou, E. (2003). Krulik, S., Rudnick, J.A, E Milou, E. 2003. Teaching Mathematics in Middle School: A Practical Guide. USA: Pearson Education.

Kurniawan, A. (2010). Peningkatan Kemampuan Penalaran Mahasiswa Calon Guru Matematika dalam Pemecahan Masalah Melalui Pembelajaran Problem Posing. Media Pendidikan Matematika, 4(1), 34-40. https:/ / doi.org/10.1109/CVPR.2018.00577

Lee, Y., Bicer, A., Kwon, H., \& Capraro, R. M. (2019). Pre-service Teachers' Preparedness for Problem Posing: Pedagogical Content Knowledge and Subject Matter Knowledge. International Journal of Education, Arts, and Science, 5(10), 13-30. https://doi.org/10.1017/CBO9781107415324.004

Mallart, A., Font, V., \& Diez, J. (2018). Case study on mathematics pre-service teachers' difficulties in problem posing. Eurasia Journal of Mathematics, Science and Technology Education, 14(4), 1465-1481. https://doi.org/10.29333/ejmste/83682

Park, J. H., \& Nunes, T. (2001). The development of the concept of multiplication. Cognitive Development, 16(3), 763-773. https://doi.org/10.1016/S08852014(01)00058-2

Project, N. P. D. (2007). Teaching Multiplication and Division. Wellington, New Zealand: The Miistry of Education.

Silver, E. A., \& Cai, J. (1996). An Analysis of Arithmetic Problem Posing by Middle School Students. Journal for Research in Mathematics Education, 27(5), 521-539.

Silver.E.A, Mamona-Downs, Leung. S.S, K. P. . (1996). Posing Mathematical problems in a complex task environment: An Exploratory Study. Journal of Reseach Mathematics Education, 27(3), 293-309.

Singer, F. M., Ellerton, N., \& Cai, J. (2013). Problem-posing research in mathematics education : new questions and directions. Educational Studies in Mathematics, 83(1), 1-7. https://doi.org/10.1007/s10649-013-9478-2 


\section{MADRASAH}

Jurnal Pendidikan dan Pembelajaran Dasar

p ISSN: 1979-5599 | e ISSN: 2502-194X

Page | 73

Stoyanova, E., \& Ellerton, N. F. (1996). A framework for research into students' problem posing in school mathematics. In P. Clarkson (Ed.), Technology in mathematics education (pp. 518-525). Melbourne: Mathematics Education Research Group of Australasia.

Tichá, M., \& Hošpesová, A. (2013). Developing teachers' subject didactic competence through problem posing. Educational Studies in Mathematics, 83(1), 133-143. https:/ / doi.org/10.1007/s10649-012-9455-1

Toluk-Uçar, Z. (2009). Developing pre-service teachers understanding of fractions through problem posing. Teaching and Teacher Education, 25(1), 166-175. https://doi.org/https:/ / doi.org/10.1016/j.tate.2008.08.003

Vula, E., \& Berdynaj, L. (2011). Collaborative Action Research : Teaching of Multiplication and Division in the Second Grade of Primary School. Journal of Qualitatif Inquiry, 2(2), 7-16. 